\title{
Do Gastroenterologists Consider Aflatoxins as Origin of Digestive System Cancers?
}

\section{Magda Carvajal-Moreno*}

Department of Botany, National Autonomous University of Mexico, Mexico

*Corresponding author: Carvajal-Moreno M, Department of Botany, National Autonomous University of Mexico, Delegation Coyoacan, 04510 Mexico, Tel: (52) 5525238197; E-mail: magdac@ib.unam.mx

Received date: Sep 15, 2017; Accepted date: Oct 04, 2017; Published date: Oct 11, 2017

Copyright: (C) 2017 Carvajal-Moreno M. This is an open-access article distributed under the terms of the Creative Commons Attribution License, which permits unrestricted use, distribution and reproduction in any medium, provided the original author and source are credited.

\begin{abstract}
Aflatoxins are important etiological factors for cancers in the digestive system that have not been extensively studied. The present review describes reports of the presence of aflatoxins in cancers of the esophagus, stomach, pancreas, liver, colon and rectum. The presence of $A F B_{1}-F A P Y$ adducts and mutations in codon 249 of the tumor suppressor gene p53 in colorectal cancer tumors and Ki-ras activation by point mutation in pancreas cancer are reliable criteria to accept AFs as an important etiological factor. The Ministries of Health of the different countries should perform more preventive practices on crops in the field and in warehouses; they should chemically analyze aflatoxins in fresh and industrialized foods for humans and feeds for animals to avoid the presence of these dangerous toxins.
\end{abstract}

Keywords: Aflatoxins; Carcinogens; Digestive system; Food contamination

\section{Introduction}

Gastroenterologists, especially hepatologists, know the nature and properties of aflatoxins: they are well accepted mutagens, teratogens, immuno-depressors and carcinogens for humans [1] present in multiple human foods, but they are not given adequate attention.

\section{Aflatoxins \\ Aflatoxins (AFs) are the most frequent carcinogen in food for humans and animal feed, such as vegetables (chilli-pepper [2], maize [3], oilseeds such as nuts [4], peanuts [5], etc.), their derivative products (industrialized chili sauces [6], tortillas [7], beers [8], dry fruits [9], peanut butter [10], etc.) and aflatoxins of animal derivative foods (eggs [11], milk [12, 13], human maternal milk [14], cheese[15,16], hens breast [17], liver [18], sausages [19], pâté [11], etc.). Many cosmetics have aflatoxins from their vegetable sources (almond oils [20] and cosmetic creams [21], hair dyes [22] made from chili pepper, etc.) and AFs can enter through the skin or the scalp.}

AF's are secondary metabolites, polyketides that chemically correspond to a bisdihydrodifuran or tetrahydrobisfuran united to a coumarin substituted by a cyclopentanone or a lactone [23-25]. AFs are divided into two subgroups [24-27].

- Bisfuran-coumarin-cyclo pentanons, which include AFs of series $B$ $\left(\mathrm{AFB}_{1}, \mathrm{AFB}_{2}, \mathrm{AFB}_{2 \mathrm{a}}\right), \mathrm{M}\left(\mathrm{AFM}_{1}, \mathrm{AFM}_{2}, \mathrm{AFM}_{2 \mathrm{a}}\right), \mathrm{Q}\left(\mathrm{AFQ}_{1}\right)$ and $\mathrm{P}$ $\left(\mathrm{AFP}_{1}\right)$ and aflatoxicol (AFL) that interconverts with $\mathrm{AFB}_{1}$.

- Bisfuran-coumarin-lactones, which contain AFs of series $G\left(A_{F G}\right.$, $\mathrm{AFG}_{2}, \mathrm{AFG}_{2 \mathrm{a}}$ ).

Only $\mathrm{AFB}_{1}, \mathrm{AFB}_{2}, \mathrm{AFG}_{1}$ and $\mathrm{AFG}_{2}$ are naturally synthesized by toxigenic fungi. The other AFs $\left(M_{1}, M_{2}, P_{1}, Q_{1}, G_{2 a}, B_{2 a}\right.$ and AFL) are products of microbial or animal metabolism [27-31].
Animal livers protect the organism by lowering the toxicity of $\mathrm{AFB}_{1}$ via the addition of an $\mathrm{OH}$ - group to form hydroxylates (AFM1, AFP1, AFQ1 and AFL); this step facilitates AF solubility in water and their disposal via urine, faeces and milk. $\mathrm{AFB}_{1}$ and AFG1 have a double bond at the 8,9 position that oxidizes and forms $\mathrm{AFB}_{1}$-exo-8,9epoxide, an unstable molecule, which produces dihydrodiol $\mathrm{AFB}_{1}$ and becomes linked to the $\mathrm{N}^{7}$-guanine of $\mathrm{DNA}$ [32] to form active carcinogens called $\mathrm{AFB}_{1}$-DNA adducts. $\mathrm{AFB}_{2}$ and $\mathrm{AFG} 2$ [33] lack a double bond, which affects their toxicity. The bond changes that conversion.

$\mathrm{AFB}_{1}$ to $\mathrm{AFB}_{2}$ are well studied $[32,34]$ and the biotransformation and biosynthetic routes of $\mathrm{AFB}_{1}$ have been previously described [18-21]. Aflatoxins damage the digestive system and the active carcinogen $\mathrm{AFB}_{1}$ formamido-pyrimidine $\left(\mathrm{AFB}_{1}\right.$-FAPY adduct) has been recovered, identified and quantified in cancer tumors from the liver, intestines, colon and rectum [35]; and has also been recovered in cervical cancer [36], the pancreas and malignant human breast tumors [35]. The effects of aflatoxin $\mathrm{B} 1\left(\mathrm{AFB}_{1}\right)$ intake, genetic polymorphisms of $\mathrm{AFB}_{1}$ metabolic enzymes and interactions between the polymorphisms and intake of $\mathrm{AFB}_{1}$ have been investigated regarding the risk of gastric cancer in Korea [37]. The results suggested that dietary $\mathrm{AFB}_{1}$ exposure might be associated with a risk of gastric cancer, but the authors did not measured $\mathrm{AFB}_{1}$-DNA adducts, which are the active carcinogens. However, the effect of $\mathrm{AFB}_{1}$ on gastric carcinogenesis may not be modulated by genetic polymorphisms of $\mathrm{AFB}_{1}$ metabolic enzymes [37]. Other studies on the digestion process of maize tortilla showed that $\mathrm{pH}$ was an important factor to activate the carcinogen [38]. Aflatoxins have a synergetic relationship with some viruses, such as hepatitis B virus [39] and human papilloma virus (HPV), particularly more with $16 \mathrm{HPV}$ than $18 \mathrm{HPV}$ [36].

Aflatoxins can cause damage in most living creatures, from viruses to humans [40-42] and they also damage plants [43]. The damage caused by aflatoxins to plants has been reported as a reduction in seed germination, suppression of the synthesis of chlorophyll and development of radicula in Lepidium sativum [44] and lettuce [45]. 
Aflatoxins inhibited the growth of algae such as Chlorella pyrenoidosa [46], among their effects on molds [47]. $\mathrm{AFB}_{1}$ inhibited the growth of four isolates of its own producing fungi Aspergillus flavus, A. awamori, Penicillium chrysogenum and $P$. duclauxi. Aflatoxins also affect fungi by inhibiting the sporulation of Aspergillus niger, Penicillium expansum, Cladosporium herbarum, Mucor hiemalis, Rhizopus nigricans and Thamnidium elegans with distinct deformations [48, 49].

\section{Experimental}

\section{Biomarkers}

The early identification of AF metabolites in human fluids [50] stimulated the development of biomarkers [51]. The availability of specific antibodies helps detect the AF metabolites in human urine [52-54].

Aflatoxins are recognized biomarkers for the risk of cancer as a result of nearly 57 yrs of study and they represent one of the most extensive data sets that assist the future studies of other environmental agents [27].

The application of biomarkers, validated in epidemiological studies, is useful to prevent high-risk human populations from cancer. The experimental and human studies of aflatoxin biomarkers are based on their biochemistry and toxicology. This systematic approach provides encouragement for preventive interventions [55].

An exposure biomarker is the present and past measurement of the exposures of AFs and their metabolites or products in the human body or fluids. The biomarkers of internal doses and of doses of biologically effective AF are generally hydroxylated metabolites and the AF-DNA adducts formed from epoxide derivatives [56]. Biomarkers in etiological research are used for prevention in high risk populations because experimental studies have established time links between AF biomarker modulation and the risk of disease.

In the body, $\mathrm{AFBs}$, mainly $\mathrm{AFB}_{1}$, are biotransformed into various metabolites, especially active $\mathrm{AFB}_{1}$-exo-8, 9-epoxide. The $\mathrm{AFB}_{1} 8$, 9epoxide $\mathrm{AFB}_{1}$ and other metabolites interact with various biomolecules in the body, including DNA, RNA and the various metabolic pathways, such as protein synthesis, glycolytic pathway and the electron transport chain involved in ATP production in cells. AFB interacts with DNA to form AFB-DNA adducts causing DNA mutations and breakages. $\mathrm{AFB}_{1}$ and its metabolites induce the up regulation of nuclear receptors, such as pregnane $\mathrm{X}$ receptor (PXR), constitutive androstane receptor (CAR) and aryl hydrocarbon receptor $(\mathrm{AhR})$, through gene expression that regulates metabolizing enzymes, such as CYP450 involved in Phase I and Phase II metabolism of xenobiotics. $\mathrm{AFB}_{1}$ activates these nuclear receptors to produce the metabolizing enzymes.

Cytochrome $\mathrm{P} 450$ controls $\mathrm{AF}$ adduct formation in the $\mathrm{AFB}_{1}$ metabolic pathway. The 8, 9-epoxide $\mathrm{AFB}_{1}$ is an electrophilic metabolite that covalently reacts with DNA to form adducts that have the carcinogenic and mutagenic activities of $\mathrm{AFB}_{1}$. The 8, -epoxide $\mathrm{AFB}_{1}$ links to $\mathrm{N}^{7}$ of the guanine residues of DNA to form the 8, 9dihydroxy-8- $\left(\mathrm{N}^{7}\right)$ guanyl-9-hydroxy $\mathrm{AFB}_{1}$ adducts $\left(\mathrm{AFB}_{1}-\mathrm{Gua}\right)$, which are the most abundant [57-59]. The positively charged imidazol ring of $\mathrm{AFB}_{1}$-Gua promotes depurination, leading to an apurinic base. This ring opens to form a chemically and biologically more stable adduct, the formamidopyrimidine; the 2, 3-dihydro-2-(N-formyl)-2', 5',6'- triamino- $4^{\prime}-4^{\prime}$-oxy-N-pyrimidyl-3-hydroxy- $\mathrm{AFB}_{1}$ $\left(\mathrm{AFB}_{1}-\mathrm{FAPY}\right)$ adduct can be present several times in DNA replication in a variety of organs [60-61] and represents the long term accumulation of years, of the persistant secondary adduct of the carcinogen in the DNA. The $\mathrm{AFB}_{1}$-FAPY adduct is indicative of persistent exposure to AFB and this may be contributing to the cancer risk [35]. Aflatoxins may in fact be a risk factor for cancer induction in a variety of organs in man, in the same manner as that of cigarette smoking. The detection of $\mathrm{AFB}_{1}$-DNA adducts in "normal" individuals and the lack of adducts in some cancer patients indicates that either a) some individuals lack the specific $\mathrm{P} 450$ isozymes required to produce the epoxide; b) they have high levels of the glutathione transferase isozyme required for detoxififcation; c) they have extremely efficient repair systems; d) they have never been exposed to $\mathrm{AFB}_{1}$ or have adduct levels below the minimum detection level of this system $\left(30 \mathrm{pg} \mathrm{AFB}_{1}\right)$ [35]. The activation of the metabolic pathway of $\mathrm{AFB}_{1}$ has been described previously [59].

For these reasons, it is important to determine the presence of free $\mathrm{AFs}\left(\mathrm{AFB}_{1}, \mathrm{AFB}_{2}, \mathrm{AFG}_{1}, \mathrm{AFG}_{2}\right)$ as an exposure measure of a person to food $A F s$ and to measure the metabolic hydroxylates $\left(\mathrm{AFM}_{1}, \mathrm{AFM}_{2}\right.$, $\mathrm{AFP}_{1}$ and $\mathrm{AFL}$ ) as biomarkers of internal doses and effective biological doses in control samples, as well as the presence of the $\mathrm{AFB}_{1}$-Gua and $\mathrm{AFB}_{1}$-FAPY adducts, which are etiological agents of human cancers, particularly hepatocellular carcinoma (HCC).

\section{Epigenetics}

The term epigenetics refers to heritable changes in gene expression (active versus inactive genes) that do not involve changes to the underlying DNA sequence, thus a change in phenotype without a change in genotype. Epigenetics refers to external modifications to DNA that turn genes "on" or "off". These modifications do not change the DNA sequence, but instead, they affect how cells "read" genes and affect gene expression rather than altering the genetic code itself. The 8, 9-epoxide $\mathrm{AFB}_{1}, \mathrm{AFB}$ and other metabolites also affect epigenetic mechanisms, including DNA methylation, histone modifications, maturation of miRNAs as well as the daily formation of single nucleotide polymorphisms (SNPs) where AFB exposure may facilitate the process and induce $\mathrm{G}: \mathrm{C}$ to $\mathrm{T}: \mathrm{A}$ transversions at the third base in codon 249 of TP53, causing the p53 mutations reported in HCC [62]. The transversion is not a epigenetic mechanism because it changes the DNA sequence, but it affects the epigenetic mechanisms. There is a multiplicative effect on HCC risk resulting from the mutational effect of aflatoxin on TP53, as monitored by detection of plasma 249 (ser), with concomitant chronic infection with HBV. The changes in epigenetic mechanisms affect gene expression, cellular differentiation and growth. $\mathrm{AFB}_{1}$ also through epigenetic mechanisms, promotes tumorigenesis, angiogenesis, invasion and metastasis in HCC. However, formation of the small amounts of $\mathrm{AFB}_{1}$ from $\mathrm{AFB}_{2}$ is suspected to cause the carcinogenicity of $\mathrm{AFB}_{2}$ in humans and animals. Chronic AF exposure leads to the formation of reactive 8, 9-epoxide $\mathrm{AFB}_{1}$ metabolites in the body that could activate and de-activate the various epigenetic mechanisms leading to the development of various cancers [63]. Aflatoxins as etiological factors of some human cancers from the digestive system will be described.

\section{Aflatoxins in Buccal cancer}

There are no conclusive studies that prove the relationship between AFs and buccal cancers although these toxins are present in many foods chewed in the mouth, such as cereals, chilli peppers and oilseeds. Some chemoprotection trials have been performed on buccal mucosal 
cells, but the results are preliminary and inconclusive. More studies are needed to clarify the etiology of these buccal cancers.

\section{Aflatoxins in Oesophageal cancer}

The accepted epidemiological risk factors for esophageal cancer development are Barrett's esophagus, obesity, tobacco, opium consumption, hot tea drinking, poor oral health and low intake of fresh fruit and vegetables [64], with no mention of AFs.

There are a few reports about aflatoxin contamination of wheat flour and the risk of esophageal cancer in a high risk area of Golestan province in North-eastern Iran. There was a positive relationship between the AF level of white flour samples and the risk of esophageal cancer in Iran. The humidity and temperature of silos were the most important determinants of AF contamination of white flour [65]. There are some reports about human immunodeficiency virus (HIV) transmission frequency being positively associated with maize consumption in Africa. HIV and esophageal cancer deaths were significantly related to maize but were inversely related to the percentage of Muslims and rice consumption [66]. Regarding the relationship between cancer and food, these authors suggests that fumonisin contamination rather than aflatoxin is the most likely factor in maize promoting HIV and esophageal cancer; this finding could be true, as fumonisins promote cancer, but to determine if the real carcinogen is $\mathrm{AFB}_{1}$, a study on $\mathrm{AFB}_{1}$-DNA adducts is needed $[66,67]$.

In the last $30 \mathrm{yrs}$, the incidence of esophageal and gastric adenocarcinoma has steadily increased approximately seven-fold, a greater increase than that of several malignancies, including melanoma, breast cancer and prostate cancer. The main risk factors for gastroesophageal junction cancer are a history of GERD and obesity [68].

\section{Aflatoxins in Stomach cancer}

In general, cancer begins when an error (mutation) occurs in a cell's DNA. The mutation causes the cell to grow and divide quickly and to be more resistant to death than the normal cells. Later, metastasis occurs invading nearby tissues and organs. Knowing that AFs are recognized mutagens, it is highly probable that they can cause stomach cancer, but it has not been proven. There is a strong correlation between a diet high in smoked and salted foods and stomach cancer in the main part of the stomach. As the use of refrigeration for preserving foods has increased around the world, the rates of stomach cancer have declined [69].

The risk factors for cancer in the gastroesophageal junction are associated with having gastrointestinal reflux disease (GERD) and, less strongly, with obesity and smoking. GERD is a condition caused by frequent backflow of stomach acid into the esophagus [70,71]. There is a report, with AFs chemical analysis, about an Italian woman with intense abdominal pain and heavy inflammation caused from the ingestion of beef contaminated with aflatoxins [72]. In well-developed countries aflatoxins exposure should be considered in case of unexplained abdominal symptoms. Cancer risk cannot be assessed, nevertheless individual counselling and periodical medical examinations are recommended.

The factors that increase the risk of stomach cancer have been previously reported $[68,73]$ and include eating foods contaminated with aflatoxins, a diet high in salty and smoked foods and low in fruits and vegetables, a family history of stomach cancer, infection with
Helicobacter pylori, long-term stomach inflammation, pernicious anemia, smoking and stomach polyps. The effects of $\mathrm{AFB}_{1}$ intake, genetic polymorphisms of $\mathrm{AFB}_{1}$ metabolic enzymes and interactions between the polymorphisms and intake of $\mathrm{AFB}_{1}$ have been investigated regarding the risk of gastric cancer in Korea [37]. The study included 477 gastric cancer patients and 477 age and sex-matched control subjects. The probable daily intake of $\mathrm{AFB}_{1}$ was significantly higher among gastric cancer patients than among control subjects and increased $\mathrm{AFB}_{1}$ intake was significantly associated with an elevated risk of gastric cancer (odds ratio 1.94; $95 \%$ confidence interval 1.43 to 2.63). The results suggested that dietary $A_{F B}$ exposure might be associated with a risk of gastric cancer, but the authors did not measure $\mathrm{AFB}_{1}$-DNA adducts, which are the active carcinogens.

Moreover, there was no interaction between $\mathrm{AFB}_{1}$ intake and the genotypes of metabolic enzymes that affect gastric cancer risk [37]. Other studies showed that, in the digestion process of maize tortilla with AFs, a neutral $\mathrm{pH}$ was an important factor to activate the carcinogen; the stomach has an acidic $\mathrm{pH} \pm 2.5$ in which the $\mathrm{AFB}_{1}$ is not activated, with the AF mutagenicity tested which with an Ames test, which might protect the individual from the formation of stomach cancer [38]. Thus, dietary $\mathrm{AFB}_{1}$ exposure might be associated with a risk of gastric cancer [37].

\section{Aflatoxins in Liver cancer}

Aflatoxins are well recognized as a cause of liver cancer $[35,39,41,58]$, with additional important toxic effects, such as immune depression and interference of protein metabolism and with multiple micronutrients basic to health. These effects have been well studied in animals but less so in humans, but some of the effects observed in animals also occur in humans. The prevalence and human exposure to aflatoxins is approximately 4.5 billion persons living in developing countries, who are chronically exposed to largely uncontrolled amounts of the toxin [67].

The aflatoxin exposure and toxic effects result in changes in nutrition and immunity that affect health, including HIV infection, which accounts for approximately $40 \%$ of the burden of disease in developing countries where a short lifespan is prevalent. Food systems and economics make the management of aflatoxins impractical in developing-country settings, but the strategy of using food additives to protect farm animals from the toxins may also provide effective and economical new approaches to protecting human populations [67].

\section{Oncogenes and tumour suppressor gene p53}

Oncogenes, such as N-ras, c-myc or c-fos, are over-expressed, but their mutations are rare and there is little evidence of a direct implication for pancreatic cancer [74]. A specific mutation in codon 249 of the p53 gene is present in regions with hepatocellular carcinomas (HCC) and high exposure to AF [75]. This mutation, induced by the reactive forms of $\mathrm{AFB}_{1}$, is a "hotspot" for the mutation induced by $\mathrm{AFB}_{1}$, specifically the transversion GC $\rightarrow \mathrm{TA}$ [59]. In Gambia, this mutation was detected in DNA in cases of HCC and was not frequent in the control cases [76-79]. Transversions $G \rightarrow T$ or transitions $\mathrm{G} \rightarrow \mathrm{A}$ are produced in the third base of codon 249 of the p53 gene and in the first or second base of codon 12 of the $\mathrm{H}$-ras gene [80-85].

$\mathrm{AFB}_{1}$ in liver cancer in rats was identified with an increase in the expression of c-myc and c-Ha-ras and in one of the tumors, an amplification and adjustment of the c-Ha-ras oncogene was observed 
[86]. When 12 tumors induced by $\mathrm{AFB}_{1}$ were examined in rats, the genomic DNA of the 10 tumors was transformed and $2 / 8$ had activated Ki-ras [87]. When male Fisher rats were exposed to $\mathrm{AFB}_{1}$ and AFG1, four liver tumors were induced, three had activated $\mathrm{N}$-ras and one had a transversion $\mathrm{G} \rightarrow \mathrm{A}$ in codon 12 of Ki-ras [88].

The tumor suppressor p53 plays an important role in the development of HCC, as well as other oncogenes and tumor suppressor genes. The identification of a specific mutation in the tumor suppressor gene p53 in HCC of world regions with high AF exposure has helped identify $\mathrm{AF}$ as a biomarker [89].

The mutation of the tumor suppressor p53 gene was found in 53\% of the HCC cases in Mexico, a country with high exposure to $\mathrm{AFB}_{1}$, while in populations with low exposure to this toxin, the mutations were observed in $26 \%$ of the cases [90]. In Senegal where people are exposed to high concentrations of $\mathrm{AFB}_{1}$ in foodstuffs, the 249 codon mutation of the p53 gene was found in 10/15 of HCC tumors [91]. The mutation index in the p53 gene is higher in tumors with a prevalence of Hepatitis B Virus (HBV) compared with tumors with Hepatitis C Virus (HCV) and non-viral HCC and independent of the AF exposure [92].

\section{Aflatoxins in Colorectal cancer}

The most complete study on aflatoxins in colorectal cancer was reported [35] with the amount of $\mathrm{AFB}_{1}$-FAPY adducts in different sections of the colon and rectum. The link between constipation and colorectal cancer is natural due to the union of the food carcinogen and the internal surface of the colon, while in non-constipated cases, the excretion of the food carcinogens is more likely. The possibility of endogenous aflatoxin production by a species of Aspergillus or other aflatoxin-producing fungi colonizing the gut is another possibility [35]. Another report refers to the acute effects of aflatoxin in rat proximal and distal colon spontaneous contractions [93].

\section{Aflatoxins in Pancreas cancer}

There are reports of aflatoxin $\mathrm{B} 1\left(\mathrm{AFB}_{1}\right)$-DNA adduct detection in formalin-fixed tissue from an acute poisoning incident in Southeast Asia [94]. Tumor tissues tended to have higher adduct levels than normal tissue from the same individual and the levels generally increased with patient age. In samples analyzed by HPLC, the adducts present had chromatographic properties of $\mathrm{AFB}_{1}$-FAPY, the open-ring form of the $\mathrm{AFB}_{1}$-guanine adduct.

In addition to a very high frequency of Ki-ras activation by point mutation [95], such as those caused by AF, there is evidence of an autocrine loop involving the overexpression of transforming growth factor alpha and the epidermal growth factor receptor [96, 97]. These abnormalities may be linked as there is in vitro evidence that activation of ras oncogenes causes upregulation of TGF alpha expression [98]. The same phenomenon occurs when aflatoxins mutate DNA.

\section{Results and Discussion}

\section{Protection mechanisms: Glutathione (GSH)}

GSH is an important antioxidant in plants, animals, fungi and some bacteria and archaea, preventing damage to important cellular components caused by reactive oxygen species, such as free radicals, peroxides, lipid peroxides and heavy metals [99].

\section{Glutathione S-transferase (GST) enzymes}

The GSTs are a family of enzymes that protect the organism. In Phase I of cytochrome P450, there are reactions to generate hydrosoluble products. In Phase II, the glutathione S-transferases (GSTs) allow these metabolites to combine with polar endogenous molecules to form conjugation products that are excreted quickly [100]. With this reaction, the solubility of dangerous compounds increases for their excretion [101]. In this same Phase II of the enzymatic de-intoxication, many electrophilic metabolites, such as xenobiotic derivates and endogenous molecules, such as aflatoxins, have carcinogenic and genotoxic effects [102-104].

\section{Glutathione S-transferase and aflatoxins}

$\mathrm{AFB}_{1}$ induces enzymatic conjugation reactions mediated by GST to inactivate the 8, 9-epoxide $A_{F B}$. Spontaneously, 8, 9-epoxide $A_{F B}$ is hydrolyzed to 8, 9 dihydrodiol and conjugates with GSH to form $\mathrm{AFB}_{1}$ glutathione transferase $\left(\mathrm{AFB}_{1}-\mathrm{SG}\right)$ [105]. The conjugate $\mathrm{AFB}_{1}-\mathrm{SG}$ is the most abundant biliary metabolite and it is excreted by urine [106]. The induction of GST and aldehyde- $\mathrm{AFB}_{1}$ reductase (AFAR) reduces the formation of adducts AF-ADN and AF-proteins and blocks cancer initiation in rats and this formation of $\mathrm{AFB}_{1}$ to $\mathrm{ADN}$ is avoided in different species. The ingestion of antioxidants in the diet increases the levels of GST and more AFB-SG is eliminated in the urine of treated animals [106].

\section{Conclusion}

Aflatoxins are the most frequent carcinogen daily ingested in multiple foods and they are an important etiological factor for cancers in the digestive system that have not been thoroughly studied. The presence of $\mathrm{AFB}_{1}$-FAPY adducts and mutations in codon 249 of the tumor suppressor gene p53 in many cancer tumors such as colorectal cancer tumors and Ki-ras activation by point mutation in pancreas cancer, are criteria to accept AFs as an important etiological factor. The Ministries of Health of the different countries should perform more preventive practices on crops in the field and in warehouses; they should chemically analyze aflatoxins in fresh and industrialized foods for humans and feeds for animals to avoid the presence of these dangerous toxins.

\section{References}

1. IARC, International Agency for the Research on Cancer (2002) Working group on the evaluation of carcinogenic risks to humans some traditional herbal medicines, some mycotoxins, naphthalene and styrene. IARC Monogr Eval Carcinog Risks Hum 82:1-556.

2. Rosas-Contreras C, Carvajal-Moreno M, Rojo-Callejas F, Ruiz-Velasco S, et al. (2016) Identification and HPLC quantification of aflatoxins in dried chili peppers (Capsicum annum L.) in Mexico and other countries. J Drug Metab Toxicol 7:198.

3. Liu Z, Gao J, Yu J (2006) Aflatoxins in stored maize and rice grains in Liaoning Province, China. J Stor Prod Res 42: 468-479.

4. Adaya-Gonzalez J, Carvajal-Moreno M, Rojo-Callejas F, Ruiz-Velasco S (2015) Aflatoxins in walnut (Juglans regia L.), pecan (Carya illinoinensis (Wangenh.) K. Koch) and cashew (Anacardium occidentale L.) nuts of Mexico. Pharm Anal Acta 6: 338-348.

5. Alvarado-Hernández JR, Carvajal-Moreno M, Rojo-Callejas F, RuizVelasco S (2016) Aflatoxins in natural peanuts (Arachis hypogaea L.) of Mexico: Validation of the biochemical methods for extraction and quantification. J Plant Biochem Physiol 4:168. 
6. Carvajal-Domínguez HG, Carvajal-Moreno M, Ruiz-Velasco S, AlvarezBañuelos MT (2016) Presence of Aflatoxins (Mutagens and Carcinogens) in Industrialized Chili sauces. Pharm Anal Acta 7: 477.

7. Castillo-Urueta P, Carvajal M, Méndez I, Meza F, Gálvez A (2011) Survey of aflatoxins in maize tortillas from Mexico City. Food Addit Contam: Part B: Surveillance 4: 42-51.

8. Mably M, Mankotia M, Cavlovic P, Tam J, Wong L, et al. (2005) Survey of aflatoxins in beer sold in Canada. Food Addit Contam 22: 1252-1257.

9. Muhammad M, ZafarIqbal S, Rafique-Asi M, Malik N (2015) Natural occurrence of aflatoxins in dry fruits and edible nuts. Food Control 55: 62-65.

10. Mupunga I, Lebelo SL, Mngqawa P, Rheeder JP, Katerere DR (2014) Natural occurrence of aflatoxins in peanuts and peanut butter from Bulawayo, Zimbabwe. J Food Prot 77: 1814-1818.

11. Amirkhizi B, Arefhosseini SR, Ansarin M, Nemati M (2015) Aflatoxin $\mathrm{B} 1$ in eggs and chicken livers by dispersive liquid-liquid microextraction and HPL. Food Addit Contam Part B Surveillance 8: 245-249.

12. Carvajal M, Bolanos A, Rojo F, Méndez I. (2003) Aflatoxin M1 in pasteurized and ultrapasteurized milk with different fat content in Mexico. J Food Prot 66: 1885-1892.

13. Carvajal M, Rojo F, Méndez I, Bolaños A (2003) Aflatoxin B1 and its interconverting metabolite aflatoxicol in milk: Situation in mexico. Food Addit Contam 20: 1077-1086.

14. Kang'the EK, Gatwiri M, Sirma AJ, Ouko EO, Mburugu-Musoti CK, et al. (2017) Exposure of kenyan population to aflatoxins in foods with special reference to nandi and makueni counties. Food Quality and Safety 1: 131-137.

15. Hernández-Camarillo E, Carvajal-Moreno M, Robles-Olvera VJ, VargasOrtiz MA, Salgado-Cervantes MA, et al. (2016) Quantifying the levels of the mutagenic, carcinogenic hydroxylated aflatoxins (AFM1 and AFM2) in Artisanal Oaxaca-type cheeses from the city of Veracruz, Mexico. J Microb Biochem Technol 8: 491-497.

16. Vargas-Ortiz M, Carvajal-Moreno M, Hernandez-Camarillo E, RojoCallejas F, Ruiz-Velasco S (2017) Unreported aflatoxins and hydroxylate metabolites in artisanal Oaxaca cheese from Veracruz, Mexico. Biochem Anal Biochem 6: 322.

17. Diaz-Zaragoza M, Carvajal M, Mendez-Ramirez I, Chilpa-Galvan NC, Avila-Gonzalez E, et al. (2014) Aflatoxins, hydroxylated metabolites and aflatoxicol from breast muscle of laying hens. Poultry Sci 93: 3152-3162.

18. Quezada T, Cuellar H, Jaramillo-Juarez F, Valdivia AG, Reyes JL (2000) Effects of aflatoxin B (1) on the liver and kidney of broiler chickens during development. Comp Biochem Physiol C Toxicol Pharmacol 125: 265-272.

19. Kivanc M, Sert S, Hasenekoglu I (1992) Production of aflatoxins in sausage, salami, sucuk and kavurma. Nahrung 36: 293-298.

20. Sanchez-Bel P, Martinez-Madrid MC, Egea I, Romojaro F (2005) Oil quality and sensory evaluation of almond (Prunus amygdalus) stored after electron beam processing. J Agric Food Chem 53: 2567-2573.

21. El-Dessouki S (1992) Aflatoxins in cosmetics containing substrates for aflatoxin-producing fungi. Food Chem Toxicol 30: 993-994.

22. Parsa N (2012) Environmental Factors Inducing Human Cancers. Iranian J Public Health 41: 1-9.

23. Jaimez J, Fuente CA, Vazquez BI, Franco CM, Cepeda A, et al. (2000) Application of the assay of aflatoxins by liquid chromatography with fluorescence detection in food analysis. J Chromatogr A 882: 1-10.

24. Leeson S, Diaz GD, Summers JD (1995) Poultry metabolic disorders and mycotoxins. University Books, Ontario, Canada.

25. Palmgren MS, Hayes AW (1987) Aflatoxins in Food. In: Mycotoxins in foods. Food Science and Technology, A Series of monographs. (eds). Academic Press. San Diego, USA.

26. Nakai VK, Rocha LO, Goncalez E, Fonseca H, Ortega, et al. (2008) Distribution of fungi and aflatoxins in a stored peanuts variety. Food Chem 106: 285-290.
27. Rastogi SC, Heydorn S, Johansen JD, Basketter DA (2001) Fragrance chemicals in domestic and occupational products. Contact Dermatitis 45: 221-225.

28. Akiyama H, Goda Y, Tanaka T, Toyoda M (2001) Determination of aflatoxins B1, B2, G1 and G2 in spices using a multifunctional column clean-up. J Chromatogr A 932: 153-157.

29. Lindner E (1995) Food Toxicology. 2nd edn. Acribia SA Saragossa, Spain.

30. Otta KH, Papp E, Bagocsi B (2000) Determination of aflatoxins in food by overpressured-layer chromatography. J Chromatogr A 882: 11-16.

31. Williams J, Wilson D (1999) Report on the problem of chestnut aflatoxins (Bertholletia excelsa) in Bolivia, Technical document 71/1999. University of Georgia, USAID/Bolivia 71: 4-7.

32. Derache J (1990) Toxicology and Food Safety. Omega, Barcelona, Spain 73-88.

33. Proctor AD, Ahmedna M, Kumar JV, Goktepe I (2004) Degradation of aflatoxins in peanut kernels/flour by gaseous ozonation and mild heat treatment. Food Addit Contam 21: 786-793.

34. Sweeney MJ, Dobson ADW. (1999) Molecular biology of mycotoxin biosynthesis. FEMS Microbiol Lett 175: 149-163.

35. Harrison JC, Carvajal M, Garner RC (1993) Does aflatoxin exposure in the United Kingdom constitute a cancer risk? Environ Health Perspect 99: 99-105.

36. Carvajal M, Berumen J, Guardado-Estrada M (2012) The presence of AFB1-FAPY adduct and human papilloma virus in cervical smears from cancer patients in Mexico. Food Addit Contam Part A Chem Anal Control Expo Risk Assess 29: 258-268.

37. Eom SY, Yim DH, Zhang Y, Yun JK, Moon SI, et al. (2013) Dietary aflatoxin B1 intake, genetic polymorphisms of CYP1A2, CYP2E1, EPHX1, GSTM1 and GSTT1 and gastric cancer risk in Korean. Cancer Causes Control 24: 1963-1972.

38. Moctezuma-Zarate MG, Carvajal M, Espinosa-Aguirre JJ, GonsebattBonaparte ME, Rojo-Callejas F, et al. (2015) Role of $\mathrm{pH}$ in the mutagenicity of Aflatoxin B1 in maize tortillas during in vitro human digestion model. J Food Nutr Disor 4: 1-10.

39. Groopman JD, Kensler TW (2005) Role of metabolism and viruses in aflatoxin-induced liver cancer. Toxicol Appl Pharm 206: 131-137.

40. Allcroft R (1969) Aflatoxicosis in farm animals. In: Goldblatt LA (ed.) Aflatoxin scientific background, control and implications. Academic Press. 237-264. New York, USA.

41. Newberne PM, Butler WH (1969) Acute and chronic effects of aflatoxin on the liver of domestic and laboratory animals. A review. Cancer Res 29: 236-250.

42. Butler WH (1974) Aflatoxin. In: Purchase IFH ed. Mycotoxins.1-28. Elsevier, Amsterdam, The Netherlands.

43. Asahi T, Mori Z, Majima R, Uritani I (1969) Effects of aflatoxins on metabolic changes in plant tissues in response to injury. J Stored Prod Res 5: 219 .

44. Schoental R, White AF (1965) Aflatoxins and albinism in plants. Nature (London) 205: 57-58.

45. Crisan EV (1973) Effects of aflatoxin on germination and growth of lettuce. Appl Microbiol 25: 342.

46. Ikawa M, Ma DS, Meeker GM, Davis RP (1969) Use of Chlorella in mycotoxin and phytotoxin research. J Agric Food Chem 17: 425-429.

47. Lillehoj, EB, Ciegler A, Hall HH (1967) Fungistatic action of aflatoxin B1. Experientia 23: 187-188.

48. Reiss J (1971) Inhibition of fungal sporulation by aflatoxin. Arch Mikrobiol 76: 219-222.

49. Reiss J (1971) Hyphenanomalien bei Thamnidium elegans Link durch Aflatoxin B1. Z Allg Mikrobiol 11: 637-638.

50. Alvarez-Banuelos MT, Carvajal-Moreno M, Mendez-Ramirez I, RojoCallejas F (2015) Free and DNA adducted aflatoxins in chronic liver diseases that predispose to hepatocellular carcinoma in Mexico. J Cancer Sci Ther 7: 274-282.

51. IARC, International Agency for the Research on Cancer (1982) IARC/ IPCS Working Group. Development and possible use of immunological 
techniques to detect individual exposure to carcinogenesis. IARC Intern. Tech Rep No 82/001, 25. Lyon, France.

52. Wild CP, Garner RC, Montesano R, Tursi F (1986) Aflatoxin B1 binding to plasma albumin and liver DNA upon chronic administration to rats. Carcinogenesis 7: 853-858.

53. Groopman JD, Donahue PR, Zhue JQ, Chen JS, Wogan GN (1985) Aflatoxin metabolism in humans: Detection of metabolites and nucleic acid adducts in urine by affinity chromatography. Proc Natl Acad Sci USA 82: 6492-6496.

54. Zhu JQ, Zhang LS, Hu X, Xiao Y, Chen JS, et al. (1987) Correlation of dietary aflatoxin B1 levels with excretion of aflatoxin M1 in human urine. Cancer Res 47: 1848-1852.

55. Jacobsen JS, Refolo LM, Conley MP, Sambamurti K, Humayun MZ (1987) DNA replication-blocking properties of adducts formed by aflatoxin B1-2, 3-dichloride and aflatoxin B1-2, 3-oxide. Mutat Res 179: 89-101.

56. Essigmann JM, Croy RG, Nadzan AM, Busby WF, Reinhold VN, et al. (1977) Structural identification of the major DNA adduct formed by aflatoxin B1 in vitro. Proc Natl Acad Sci USA 74: 1870-1874.

57. Croy RG, Essigmann JM, Reinhold VN, Wogan GN (1978) Identification of the principal aflatoxin B1-DNA adduct formed in vivo in rat liver. Proc Natl Acad Sci 75: 1745-1749.

58. Smela ME, Currier SS, Bailey EA, Essigmann J (2001) The chemistry and biology of aflatoxin B1: From mutational spectrometry to carcinogenesis. Carcinogenesis 22: 535-545.

59. Hertzog PJ, Smith JR, Garner RC (1982) Characterization of the imidazole ring-opened forms of trans-8, 9-dihydro-8, 9-dihydro-8-(7guanyl) 9-hydroxy aflatoxin B1. Carcinogenesis 3: 723-725.

60. Sotomayor RE, Washington M, Nguyen L, Nyang'anyi R, Hinton DM, et al. (2003) Effects of intermittent exposure to aflatoxin B1 on DNA and RNA adduct formation in rat liver: Dose-response and temporal patterns. Toxicol Sci 73: 329-338.

61. Kirk GD, Lesi OA, Mendy M, Szymañska K, Whittle H, et al. (2005) 249(ser) TP53 mutation in plasma DNA, hepatitis B viral infection and risk of hepatocellular carcinoma. Oncogene 24: 5858-5867.

62. Bbosa GS, Kitya D, Odda J, Ogwal-Okeng J (2013) Aflatoxins metabolism, effects on epigenetic mechanisms and their role in carcinogenesis. Health 5:14-34.

63. Mao WM, Zheng WH, Ling ZQ (2011) Epidemiologic risk factors for esophageal cancer development. Asian Pacific J Cancer Prev 12: 2461-2466.

64. Ghasemi-Kebria F, Joshaghani H, Taheri NS, Semnani S, Aarabi M, et al. (2013) Aflatoxin contamination of wheat flour and the risk of esophageal cancer in a high risk area in Iran. Cancer Epidemiol 37: 290-293.

65. Williams JH, Grubb JA, Davis JW, Wang J-S, Jolly PE, et al. (2010) HIV and hepatocellular and esophageal carcinomas related to consumption of mycotoxin-prone foods in sub-Saharan Africa. Amer J Clin Nutr 92: 154-160.

66. Williams JH, Phillips TD, Jolly PE, Stiles JK, Jolly CM, et al. (2004) Human aflatoxicosis in developing countries: A review of toxicology, exposure, potential health consequences and interventions. Am J Clin Nutr 80: 1106-1122.

67. Carr JS, Zafar SF, Saba N, Khuri FR, El-Rayes BF (2013) Risk factors for rising incidence of esophageal and gastric cardia adenocarcinoma. Journal of Gastrointestinal Cancer 44: 143-151.

68. Niederhuber JE, ed. Cancer of the stomach and gastroesophageal junction. In: Abeloff 's Clinical Oncology. 5th edn. Philadelphia, Pa: Churchill Livingstone Elsevier 2014.

69. Vial M, Grande L, Pera M (2010) Epidemiology of adenocarcinoma of the esophagus, gastric cardia and upper gastric third. Recent Results Cancer Res 182: 1-17.

70. Perduri R, Gobba S (2009) Unexpected aflatoxin exposure in a woman in northern Italy: A case report. Cases J 2: 7736.

71. Feldman M, et al. (2016) Adenocarcinoma of the stomach and other gastric tumors. In: Sleisenger and Fordtran's Gastrointestinal and Liver
Disease: Pathophysiology, Diagnosis, Management. 10th edn. Philadelphia, Pa: Saunders Elsevier.

72. Hofseth LJ, Hussain SP, Harris CC (2004) p53: 25 years after its discovery. Trends Pharmacol Sci 25: 177-181.

73. Hsu IC, Metcalf RA, Sun T, Welsh JA, Wang NJ, et al.(1991) Mutational hotspot in the p53 gene in human hepatocellular carcinomas. Nature 350: 427-428.

74. Kirk GD, Camus-Randon AM, Goedert J, Hainaut P, Montesano R (1999) P53 mutation in sera of patients with hepatocellular carcinoma and cirrhosis in The Gambia (West Africa). [Abstract], American Association for Cancer Research 90th Annual Meeting 40: 41.

75. Kirk GD, Bah E, Montesano R (2006) Molecular epidemiology of human liver cancer: Insights into etiology, pathogenesis and prevention from The Gambia, West Africa. Carcinogenesis 27: 2070-2082.

76. Kirk GD, Camus-Randon AM, Mendy M, Goedert JJ, Merle P, et al. (2000) Ser-249 p53 mutations in plasma DNA of patients with hepatocellular carcinoma from the Gambia. J Natl Cancer Inst 92: 148-153.

77. Kirk GD, Lesi OA, Mendy M, Akano AO, Sam O, et al. (2004) The Gambia Liver Cancer Study: infection with hepatitis B and C and the risk of hepatocellular carcinoma in West Africa. Hepatology 39: 211-219.

78. Hulla JE, Chen ZY, Eaton DL (1993) Aflatoxin B1-induced rat hepatic hyperplastic nodules do not exhibit a site-specific mutation within the p53 gene. Cancer Res 53: 9-11.

79. McMahon G, Davis EF, Huber LJ, Kim Y, Wogan GN (1990) Characterization of c-K-ras and N-ras oncogenes in aflatoxin B1 induced rat liver tumors. Proc Natl Acad Sci USA 87: 1104-1108.

80. Wogan GN, Hecht SS, Felton JS, Conney AH, Loeb LA (2004) Environmental and chemical carcinogenesis. Sem Cancer Biol 14: 473-486.

81. Habib SL, Said B, Awad AT, Mostafa HM, Shank RC (2006) Novel adenine adducts, N-7-guanine-AFB (1) adducts and p53 mutations in patients with schistosomiasis and aflatoxin exposure. Cancer Detect Prev 30: 491-498.

82. Kamdem LK, Meineke I, Goedtel-Armbrust U, Brockmoeller J, Wojnowski L (2006) Dominant contribution of P450 3A4 to the hepatic carcinogenic activation of aflatoxin B-1. Chem Res Toxicol 19: 577-586.

83. Hussain SP, Schwank J, Staib F, Wang XW, Harris CC (2007) TP53 mutations and hepatocellular carcinoma: Insights into the etiology and pathogenesis of liver cancer. Oncogene. 26: 2166-2176.

84. Tashiro F, Morimura S, Hayashi K, Makino R, Kawamura H, et al. (1986) Expression of the c-Ha-ras and c-myc genes in aflatoxin B1-induced hepatocellular carcinomas. Biochem Biophys Res Commun 138: 858-864.

85. McMahon G, Hanson L, Lee JJ, Wogan GN (1986) Identification of an activated c-Ki-ras oncogene in rat liver tumors induced by aflatoxin B1. Proc Natl Acad Sci USA 83: 9418-9422.

86. Sinha S, Webber C, Marshall CJ, Knowles MA, Procter A, et al. (1988) Activation of ras oncogenes in aflatoxin-induced rat liver carcinogenesis. Proc Natl Acad Sci USA 85: 3673-3677.

87. Wild CP, Hall AJ (2000) Primary prevention of hepatocellular carcinoma in developing countries. Mutat Res 462: 381-393.

88. Soini Y, Chia SC, Bennett WP, Groopman JD, Wang JS, et al. (1996) An aflatoxin-associated mutational hotspot at codon 249 in the p53 tumor suppressor gene occurs in hepatocellular carcinomas from Mexico. Carcinogenesis 17: 1007-1012.

89. Coursaget P, Depril N, Chabaud M, Nandi R, Mayelo V, et al. (1993) High prevalence of mutations at codon 249 of the p53 gene in hepatocellular carcinomas from Senegal. Brit J Cancer 67:1395-1397.

90. Laurent-Puig P, Legoix P, Bluteau O, et al. (2001) Genetic alterations associated with hepatocellular carcinomas define distinct pathways of hepatocarcinogenesis. Gastroenterology 120: 1763-1773.

91. Gursoy N, Durmus N, Bagcivan I, Sarac B, Parlak A, et al. (2008) Investigation of acute effects of aflatoxin on rat proximal and distal colon spontaneous contractions. Food and Chem Toxicol 46: 2876-2880. 
Citation: Carvajal-Moreno M (2017) Do Gastroenterologists Consider Aflatoxins as Origin of Digestive System Cancers? J Pharmacovigil 5: 242. doi:10.4172/2329-6887.1000242

Page 7 of 7

92. Harrison JC, Garner RC (1991) Immunological and HPLC detection of aflatoxin adducts in human tissues after an acute poisoning incident in SE Asia. Carcinogenesis 12: 741-743.

93. Shibata D, Capella G, Perucho M (1990) Mutational activation of the c-Kras gene in human pancreatic carcinoma. Balliere's Clinical Gastroenterology 4: 151-169.

94. Barton CM, Hall PA, Hughes CM, Gullick WJ, Lemoine NR (1991) Transforming growth factor alpha and epidermal growth factor in human pancreatic cancer. J Pathol 163: 111-116.

95. Lemoine NR, Hughes CM, Barton CM, Poulsom R, Jeffrey RE, et al. (1992) Epidermal growth factor receptor in human pancreatic cancer. J Pathol 166: 7-12.

96. Ciardello F, McGeady ML, Kim N, Basolo F, Hynes N, et al. (1990) Transforming growth factor alpha expression is enhanced in human mammary epithelial cells transformed by an activated c-Ha-ras protooncogene but not by the c-neu protooncogene and overexpression of the transforming growth factor alpha complementary DNA leads to transformation. Cell Growth Differ 1: 407-420.

97. Pompella A, Visvikis A, Paolicchi A, Tata V, Casini AF (2003) The changing faces of glutathione, a cellular protagonist. Biochem Pharmacol 66: 1499-1503.

98. Ziglari T, Allameh A, Razzaghi-Abyaneh M, Khosravi AR, Yadegari MH (2008) Comparison of Glutathione S-transferase activity and concentration in aflatoxin-producing and their non-toxinogenic counterpart isolates. Mycopathologia 166: 219-226.

99. Lumjuan N, Stevenson BJ, Prapanthadara LA, Somboon P, Brophy PM, et al. (2007) The Aedes aegypti glutathione transferase family. Insect Biochem Mol Biol 37: 1026-1035.
100. Warholm M, Guthenberg C, Bahr CV, Mannervik B (1985) Glutathione transferases from human liver. Methods Enzymol 113: 499-504.

101. Andersson C, Mosialou E, Weinander R, Morgenstern R (1994) Enzymology of microsomal glutathione S-transferase. Adv Pharmacol 27: 19-33.

102. Mannervik B, Board PG, Hayes JD, Listowsky I, Pearson WR (2005) Nomenclature for mammalian soluble glutathione Transferases. Methods Enzymol 401: 1-8.

103. Kensler TW, Egner PA, Davidson NE, Roebuck BD, Pikul A, et al. (1986) Modulation of aflatoxin metabolism, aflatoxin-N7-guanine formation and hepatic tumorogenesis in rats fed ethoxyquin: Role of induction of glutation S-transferases. Cancer Res 46: 3924-3931.

104. Groopman JD, Cain LG, Kensler TW (1988) Aflatoxin exposure in human populations: measurements and relationship to cancer. Crit Rev Toxicol 19: 113-145.

105. Egner PA, Gange SJ, Dolan PM, Groopman JD, Munoz A, et al. (1995) Levels of aflatoxin-albumin biomarkers in rat plasma are modulated by both long-term and transient interventions with oltipraz. Carcinogenesis 16: $1769-1773$

106. Kimura M, Lehmann K, Golapan P, Lotlikar PD (2004) Effect of diet on aflatoxin B1-ADN binding and aflatoxin B1-induced glutathione Stransferase placental form positive hepatic foci in rat. Exp Mol Med 36: 351-357. 